\title{
PERANAN IBU RUMAH TANGGA PADA PROGRAM KAWASAN RUMAH PANGAN LESTARI DI KECAMATAN NATAR KABUPATEN LAMPUNG SELATAN
}

\author{
(Housewives Role in a sustainable food house area program in Natar sub - District \\ South Lampung Regency)
}

M Yogi Hadi Atmadja, Kordiyana K Rangga, Indah Listiana

\begin{abstract}
Jurusan Agribisnis, Fakultas Pertanian, Universitas Lampung, Jl. Prof. Dr. Soemantri Brojonegoro No.1 Bandar Lampung 35141, Telp. 082176679697, e-mail: Yogihadiatmadja@gmail.com
\end{abstract}

\begin{abstract}
The aims of this research are to determine the level of housewives role in the KRPL Program and factors that related to the role of housewives in the KRPL Program. This research was conducted in December 2017 to January 2018 in Natar Sub - District, South Lampung District. The research used survey method in which respondents were housewives who implemented the KRPL Program in Pancasila Village and Sidosari Village as many as 40 people. Research data was analyzed descriptively and by Rank Spearman analysis test. The results of this research showed that the role of housewives in the KRPL Program were classified as high level. This was approved by the high role classification in tillage, planting, plant maintenance, harvesting, and marketing product.
\end{abstract}

Key words: housewives, role, sustainable food home area program

\section{PENDAHULUAN}

Pembangunan ketahanan pangan di Indonesia dihadapkan pada berbagai masalah pokok, yaitu: pertumbuhan permintaan pangan lebih cepat dari pertumbuhan produksinya. Secara nasional, cepatnya pertumbuhan permintaan pangan disebabkan oleh beberapa faktor antara lain adalah tingkat kemiskinan, pertumbuhan penduduk, daya beli masyarakat dan pertumbuhan industri (Saptana, Sunarsih dan Friyatno 2013).

Besarnya pengeluaran pangan yang terjadi saat ini berbanding terbalik dengan besarnya pendapatan rumah tangga, dan hal ini mencerminkan masih rendahnya pendapatan rumah tangga petani (Hernanda, Indriani dan Listiana 2013). Tingginya kemiskinan dan bertambahnya jumlah penduduk setiap tahunnya merupakan tantangan dalam pembangunan, pemerintah harus mengupayakan program - program pembangunan masyarakat dalam upaya pengentasan kemiskinan dan pemenuhan kebutuhan pangan masyarakat.

Salah satu upaya pemerintah dalam pembangunan ketahanan pangan adalah dengan meluncurkan program Kawasan Rumah Pangan Lestari (KRPL), program ini berupaya memberdayakan dan memanfaatkan sumber daya yang tersedia di sekitar masyarakat itu sendiri (Kementerian Pertanian 2011).
Program KRPL pelaksanaannya melibatkan ibu rumah tangga yang tergabung dalam Kelompok Wanita Tani (KWT). Kawasan Rumah Pangan Lestari merupakan salah satu program Kementerian Pertanian dalam rangka optimalisasi lahan pekarangan yang ramah lingkungan dalam suatu kawasan. Pada pelaksanaan kegiatannnya mengembangkan beraneka ragam komoditas pertanian yang lestari dan berkelanjutan.

Program Kawasan Rumah Pangan Lestari dimulai dari tahun 2011, merupakan program nasional yang diinisiasi dan dilaksanakan oleh Balai Pengkajian Teknologi Pertanian, setiap BPTP di Indonesia mengembangkan 1-2 lokasi setiap tahunnya pada masing - masing provinsi (Kementerian Pertanian 2011). Program ini dikembangkan dengan memanfaatkan petak lahan pekarangan atau lahan kosong disekitar rumah untuk tanaman produktif yang dibutuhkan sehari hari bagi keluarga dan mengupayakan pemberdayaan potensi pangan lokal (Badan Litbang Pertanian 2011).

Provinsi Lampung merupakan salah satu provinsi yang ikut melaksanakan program KRPL. Program KRPL di Provinsi Lampung sudah dilaksanakan sejak tahun 2012. Kabupaten Lampung Selatan merupakan pelaksana terbanyak program KRPL bersama Kabupaten Pringsewu di Provinsi Lampung, namun Kabupaten Lampung 
Selatan pada pelaksanaannya lebih berkelanjutan, dimulai dari tahun 2013, 2014 dan 2016, dengan hampir setiap tahun selalu dilaksanakannya KRPL di Kabupaten Lampung Selatan membuktikan bahwa kabupaten Lampung Selatan memiliki banyak potensi dari anggota KWT, yang bisa dikembangkan melalui KRPL untuk memenuhi kebutuhan pangan dan perekonomian keluarga petani.

Pelaksanaan KRPL di Lampung Selatan, salah satunya dilaksanakan di Kecamatan Natar, yang dengan dilaksanakan di dua desa yaitu Desa Pancasila dan Desa Sidosari. Kecamatan Natar pertama kali melaksanakan program KRPL tahun 2014 di Desa Pancasila, lalu pada tahun 2016 dilaksanakan kembali di desa yang berbeda yaitu Desa Sidosari. Berdasarkan data diketahui bahwa program KRPL dilaksanakan dengan jumlah peserta sebanyak 20 orang anggota KWT dan merata untuk setiap desa.

Hubeis (2010) menyatakan pelaksanaan pembangunan pertanian akan berhasil, jika semua sumberdaya manusia dilibatkan dalam hal ini tidak hanya pria tetapi juga wanita. Upaya yang dilakukan wanita dalam meningkatkan perannya dalam membangun pertanian salah satunya dengan memberdayakan lahan pekarangan untuk meningkatkan perekonomian dan pemenuhan pangan keluarga.

Berkaitan dengan peranan yang dijalankan antara pria dan wanita tentu berbeda, karena tingkat kemampuan tenaga antara pria dan wanita itu berbeda. Faktor ekonomi akan mengubah peranan wanita yang hanya sebagai ibu rumah tangga harus bekerja untuk memenuhi kebutuhan hidup keluarganya (Susanti dan Tantoro 2015). Penelitian Irawati dan Darojat (2019), menyatakan bahwa perananan wanita dalam keluarga dicerminkan dari profil aktivitas dan curahan waktu kerja , menunjukkan bahwa wanita bisa berperan lebih aktif dalam pembinaan keluarga dan pengambilan keputusan dibandingkan laki - laki karena kerja rumah tangga merupakan dunianya perempuan.

Peran wanita dalam keluarga tidak hanya sebagai istri untuk melayani suami dan sebagai ibu untuk anak-anaknya, namun ibu rumah tangga juga sebagai pencari nafkah untuk pemenuhan kebutuhan keluarga dan meningkatkan penghasilan keluarga. Meskipun istri bekerja mencari nafkah namun kewajibannya untuk mengurus rumah tangga tetap dilakukannya sebelum berangkat kerja dan setelah pulang bekerja (Susanti dan Tantoro 2015). Kementerian Pertanian memanfaatkan potensi tersebut untuk mewujudkan kemandirian pangan melalui upaya pemberdayaan wanita di pedesaan maupun perkotaan. Penyedian pangan harus diupayakan melalui program - program produksi pangan dalam negeri, kegiatan produksi diusahakan harus meningkat seiring dengan pertambahan penduduk (Purwaningsih 2008). Penelitian Kirana, Effendi dan Silviyanti (2018) mengatakan salah satu cara untuk mewujudkan kemandirian yaitu dengan cara mengelola potensi - potensi yang ada di desa.

Program KRPL merupakan gerakan dari masyarakat untuk masyarakat yang berkerjasama dengan para anggota kelompok wanita tani yang diharapkan mampu berkontribusi pada pengentasan kemiskinan dan perekonomian keluarga. Namun demikian terdapat hal penting terkait pertanyaan tentang sejauh mana pelaksanaan program KRPL yang telah dilaksanakan ibu rumah tangga. Berdasarkan uraian tersebut, maka tujuan dari penelitian ini adalah untuk mengetahui tingkat peranan Ibu Rumah Tangga pada program Kawasan Rumah Pangan Lestari.

\section{METODE PENELITIAN}

Penelitian ini dilakukan di Kecamatan Natar Kabupaten Lampung Selatan dengan menggunakan metode survei. Responden penelitian sebanyak 40 ibu rumah tangga, tersebar di Desa Pancasila 20 orang dan Desa Sidosari 20 orang yang tergabung pada kelompok wanita tani. Pengambilan sampel menggunakan metode sensus. Kedua lokasi dipilih secara sengaja dengan pertimbangan bahwa Kecamatan Natar merupakan pelaksana terbanyak Program Kawasan Rumah Pangan Lestari. Pengambilan data dilakukan pada bulan Desember 2017 - Januari 2018. Data primer penelitian ini diperoleh melalui wawancara langsung menggunakan kuisoner dan didukung dengan data sekunder yang diperoleh dari dinas dan instansi terkait. Metode analisis data yang digunakan adalah analisis deskriptif.

\section{HASIL DAN PEMBAHASAN}

\section{Pelaksanaan Program KRPL di Kecamatan Natar Kabupaten Lampung Selatan}

Pada tahun 2011, sebagai upaya mewujudkan ketahanan pangan Kementerian Pertanian mulai meresmikan Program Kawasan Rumah Pangan 
Lestari dan dilaksanakan di 33 provinsi di Indonesia. Pengembangan model tersebut merupakan implementasi Rencana Strategis Kementerian Pertanian 2009-2014, salah satu target Kementerian Pertanian adalah diversifikasi pangan dan pengurangan kemiskinan dengan menambah pendapatan keluarga. Program KRPL pada kegiatannya memanfaatan lahan kosong atau pekarangan tak terpakai di sekitar rumah dengan menanam tanaman sayuran dan budidaya ternak atau ikan.

Kawasan Rumah Pangan Lestari dikreasi dari salah satu budaya bangsa yang berharga, yaitu memanfaatkan pekarangan sebagai sumber bahan pangan keluarga untuk memenuhi kebutuhan pangan dan gizi sehari hari, serta menambah pendapatan keluarga. Pada pelaksanaan program KRPL masing - masing ibu rumah tangga membuat demplot atau area yang berfungsi sebagai lokasi pemanfaatan pekarangan untuk ditanami berbagai tanaman dan membuat kandang atau kolam ikan. Setiap ibu rumah tangga dalam mengembangkan KRPL membuat dan mengembangkan demplot sebagai lahan pekarangan percontohan. Lahan demplot yang dibuat diusahakan tidak berlokasi terlalu jauh dari tempat tinggal ibu rumah tangga, sehingga memudahkan proses kegiatan KRPL.

Pada penerapan kegiatan KRPL di Kecamatan Natar yang dilakukan ibu rumah tangga hanya berfokus pada kegiatan penanaman sayuran saja, sedangkan untuk ternak dan ikan tidak dilakukan lagi karena biaya untuk perawatan kolam, kandang dan pakan terlalu besar yang dirasakan oleh ibu rumah tangga sehingga kegiatan itu tidak dilanjutkan. Ibu rumah tangga lebih memilih untuk melanjutkan kegiatan yang tidak memberatkan mereka, kegiatan budidaya sayuran dipilih karena bisa dikerjakan untuk memanfaatkan waktu luang mereka dan hasil yang didapatkan juga sesuai dengan kebutuhan konsumsi pangan keluarga. Jenis tanaman yang dibudidayakan yaitu tanaman sayuran seperti sawi, bayam, kangkung, pakcoy, dan tomat kecil, sedangkan untuk ternak dan kolam tidak dilaksakan ibu rumah.

Berdasarkan hasil penelitian menunjukkan beberapa anggota kelompok KRPL telah mencapai tahap pembuatan kebun bibit dan telah dikelola secara mandiri dengan menyediakan bibit tanaman bagi keperluan pasar atau masyarakat sekitar kawasan atau desa. Pada pembuatan kebun bibit ini hanya beberapa anggota saja yang melaksanakan pembuatan kebun bibit, dikarenakan tidak tersedianya lahan untuk dijadikan kebun bibit. Pada pelaksanaan, pengelola kebun bibit mempunyai tugas : (a) bertanggung jawab terhadap pelaksanaan teknis kebun sehari-hari, (b) mencatat pemasukan dan pengeluaran barang atau bibit termasuk pembiayaannya dan (c) pengelola bertanggungjawab kepada ketua kelompok atau angota. Sebagian anggota yang tidak membuat kebun bibit hanya membantu merawat kondisi kebun agar bisa berfungsi dengan baik, untuk menyediakan bibit ketika terjadi gangguan tanaman pada pekarangan anggota yang lainnya, dengan adanya kebun bibit mampu menyuplai kebutuhan tanam para anggota karena ketersediaan bibit atau benih untuk ditanam bisa berkelanjutan.

Pada pelaksanaannya ibu rumah tangga dan pengelola kebun bibit melakukan penyemaian berbagai tanaman sayuran bagi keperluan rumah tangga yang akan menanam di pekarangan rumah masing - masing. Ketua kelompok wanita biasanya menginstruksikan kepada anggotanya dalam perawatan kebun bibit dengan pembuatan kalender tanam. Kalender Tanam ini dapat digunakan pengurus Kebun Bibit Keluarga (KBK) untuk merencanakan dan membuat persemaian tanaman.

Ibu rumah tangga dalam pembudidayaan tanamannya menerapkan sistem rotasi tanaman, dengan sistem rotasi ini diharapkan oleh mereka dapat meningkatkan produksi tanaman, memanfaatkan tanah yang kosong, memperkaya variasi tanaman sehingga ada keberagaman dan tidak itu - itu saja yang ditanam. Menurut ibu rumah tangga yang terlibat pada program KRPL adanya kegiatan rotasi bisa memperkecil resiko kegagalan panen karena akibat dari rotasi adalah memperbaiki kesuburan tanah.

Hasil kegiatan KRPL menurut ibu rumah tangga sangat membantu, dikarenakan dapat mengurangi pengeluaran konsumsi pangan dan terpenuhinya gizi rumah tangga. Kawasan Rumah Pangan Lestari membantu ibu rumah tangga dalam menyediakan bahan pangan secara mandiri. Ibu rumah tangga yang terlibat pada kegiatan apabila memerlukan bahan pangan, dapat memenuhinya dengan hasil panen dari pekarangan pribadi. Selain untuk memenuhi kebutuhan pangan rumah tangga, program KRPL juga telah membantu penghematan biaya / pengeluaran keluarga untuk konsumsi pangan yakni berkisar antara Rp250.000,00 s.d. Rp500.000,00 per keluarga. Hasil ini sejalan dengan penelitian Nurmayasari (2014), mengatakan dengan mengikuti kegiatan yang ada pada kelompok wanita tani pemasukan keluarga dapat bertambah. Selain itu, hasil dari 
kegiatan KWT dapat menekan pengeluaran rumah tangga.

\section{Peranan Ibu Rumah Tangga (Variabel Y)}

Peranan ibu rumah tangga pada Program KRPL yang dikaji dalam penelitian ini adalah peranan ibu rumah tangga dalam melakukann kegiatan pengolahan tanah, penanaman, pengendalian hama dan penyakit, pemanenan dan pemasaran hasil pada Program KRPL. Berbagai studi ataupun penelitian telah mengungkapkan bahwa wanita memiliki peran dalam pemenuhan pangan dan gizi keluarga. Wanita memiliki peranan pada setiap tahap kegiatan yang terkait dengan pertanian mulai dari usahatani sampai pengolahan pangan yang tersaji di meja makan, besar atau kecil kontribusinya tergatung pada curahan waktu dan tenaga yang digunakan. Wanita berperan pada produksi, pengolahan dan distribusi pangan di tingkat rumah tangga (Rachmawati 2012).

Hasil penilaian ibu rumah tangga terhadap pengolahan tanah, penanaman, pengendalian hama dan penyakit, pemanenan dan pemasaran hasil pada Program KRPL di Kecamatan Natar, dan rekapitulasi peranan ibu rumah tangga pada Program KRPL dengan hasil data dapat dilihat pada Tabel 2. Berdasarkan lima indikator penilaian peranan ibu rumah tangga tersebut dapat dilihat satu per satu peranan ibu rumah tangga berdasarkan indikator penilaiannya.

Berdasarkan hasil penelitian menunjukkan bahwa 45,00 persen ibu rumah tangga termasuk dalam klasifikasi tinggi, 45,00 persen lainnya termasuk dalam klasifikasi sedang, dan 10,00 persen sisanya termasuk klasifikasi rendah. Hal ini menunjukkan bahwa peranan yang dilakukan ibu rumah tangga pada program KRPL dapat dikatakan sedang. Distribusi peranan ibu rumah tangga merata pada setiap kegiatan yang dilaksanakan mulai dari pengolahan tanah hingga pemasaran hasil.

\section{Pengolahan Lahan}

Peranan ibu rumah tangga dalam pengolahan tanah sebanyak 33 orang $(82,50 \%)$ pada klasifikasi sedang, sebanyak 5 orang $(12,50 \%)$ pada klasifikasi tinggi, dan hanya 5 persen pada klasifikasi rendah. Artinya ibu rumah tangga sudah mempunyai kemauan yang cukup untuk ikut dalam pelaksanaan pengolahan tanah pada program KRPL, hasil penelitian menunjukkan bahwa ibu rumah tangga sebagai seorang wanita juga mampu untuk melakukan pekerjaan yang tergolong berat yang biasanya dikerjakan oleh laki - laki, yang sering dianggap wanita tidak mampu melakukan pekerjaan yang sulit. Peranan dalam pengolahan tanah yang dilakukan wanita meliputi mencangkul, meratakan tanah, dan membuat lubang tanam.

\section{Penanaman}

Peranan ibu rumah tangga dalam penanaman menunjukkan seluruh responden (40 orang) menyatakan tingkat peranan ibu rumah tangga masuk ke dalam klasifikasi tinggi. Artinya ibu rumah tangga sudah mampu melaksanakan kegiatan menanam sesuai dengan arahan penyuluh untuk mengoptimalisasi lahan yang tergolong sempit untuk bisa ditanami berbagi macam sayuran dalam satu lahan. Peranan dalam penanaman yang dilakukan ibu rumah tangga meliputi membuat lubang persemaian benih dan kegiatan mengangkut benih dan menanam.

\section{Pemeliharaan Tanaman}

Peranan ibu rumah tangga terhadap pemeliharaan tanaman menunjukkan sebagian besar responden sebanyak 30 orang $(75,00 \%)$ menyatakan tingkat peranan ibu rumah tangga masuk ke dalam klasifikasi tinggi, sedangkan sisanya 10 orang (25\%) termasuk klasifikasi sedang. Artinya ibu rumah tangga sudah mampu melakukan tindakan apa saja yang bisa diterapkan dalam satu lahan. Peranan dalam pemeliharaan tanaman yang dilakukan ibu rumah tangga meliputi memupuk tanaman, menyiram tanaman, mengendalikan hama dan penyakit dan menyulam.

\section{Pemanenan}

Peranan ibu rumah tangga dalam pemanenan menunjukkan sebagian besar yakni sebanyak 33 orang $(82,50 \%)$ menyatakan tingkat peranan ibu rumah tangga masuk ke dalam klasifikasi tinggi, sisanya 5 orang $(12,5 \%)$ dan 2 orang $(5 \%)$ termasuk dalam klasifikasi sedang dan rendah. Artinya responden sudah mampu melakukan peranannya secara aktif dalam pelaksanaan kegiatan program KRPL. Peranan dalam pemanenan yang dilakukan ibu rumah tangga meliputi mencabut sayuran dan mengangkut sayuran.

\section{Pemasaran Hasil}

Peranan ibu rumah tangga dalam pemasaran hasil menunjukkan sebagian besar responden sebanyak 
35 orang atau $(87,50 \%)$ menyatakan tingkat peranan ibu rumah tangga masuk ke dalam klasifikasi tinggi, sisanyan 4 orang (10\%) dan seorang $(2,5 \%)$ termasuk dalam klasifikasi sedang dan rendah. Hal ini berarti responden sudah berperan secara baik dalam pelaksanaan kegiatan program KRPL. Peranan dalam pemeliharaan tanaman yang dilakukan ibu rumah tangga meliputi pengangkutan hasil dan penjualan hasil.

Berdasarkan hasil penelitian lapang dalam melakukan peranan dalam program KRPL, ibu rumah tangga tidak melakukan kegiatan sendiri, tetapi melibatkan peran pria dalam kegiatan yang dilakukan.

\section{Peranan Ibu Rumah Tangga pada Program KRPL Dilihat dari Tingkat Curahan Kerja}

UUD 1945 sebagai landasan konstitusional menyatakan bahwa wanita mempunyai potensi yang sama dengan pria. Adanya peran yang seimbang antara pria dan wanita merupakan kunci keberhasilan pembangunan pertanian (Farmia 2006). Berdasarkan hasil penelitian lapang dalam melakukan peranan dalam program KRPL, ibu rumah tangga tidak melakukan kegiatan sendiri, tetapi melibatkan peran serta suami dalam kegiatan yang dilakukan. Pada kegiatannya bisa dilihat perbandingan antara curahan waktu yang dilakukan antara ibu rumah tangga dan suami terhadap pengolahan tanah, penanaman, pengendalian hama dan penyakit, pemanenan dan pemasaran hasil pada Program KRPL di Kecamatan Natar, dan rekapitulasi curahan waktu kerja ibu rumah tangga pada Program KRPL dapat dilihat pada Tabel 1 .

Hasil analisis curahan waktu ibu rumah tangga pada kegiatan pengolahan tanah lebih kecil yaitu 21,80 HKP dibandingkan pria 29,20 HKP dari kegiatan membajak, mencangkul ataupun meratakan tanah. Lebih kecilnya curahan waktu wanita pada pengolahan tanah ini disebabkan oleh

Tabel 1. Rekapitulasi curahan waktu suami dan ibu rumah tangga pada Program KRPL

\begin{tabular}{llcc}
\hline \multirow{2}{*}{ No } & \multirow{2}{*}{ Jenis Kegiatan } & \multicolumn{2}{c}{ Lama Hari Kerja (HKP) } \\
\cline { 3 - 4 } & & Suami & Ibu RT \\
\hline 1. & Pengolahan Tanah & 29,20 & 21,80 \\
2. & Penanaman & 14,03 & 15,60 \\
3. & Pemeliharaan & 12,53 & 29,30 \\
& Tanaman & & \\
4. & Pemanenan & 0,00 & 14,40 \\
5. & Pemasaran Hasil & 0,00 & 15,70 \\
\hline
\end{tabular}

karena menurut mereka pekerjaan mengolah tanah itu merupakan pekerjaan yang berat sehingga menjadi tugas laki - laki. Namun walaupun kegiatan pengolahan tanah ini dirasakan berat dilakukan wanita, mereka tidak berpikir untuk tidak ikut berperan dalam kegiatan pengolahan tanah. Dikarenakan mereka ingin mengetahui cara pengolahan tanah yang sesuai dengan pedoman KRPL yang akan dilaksanakan.

Peranan ibu rumah tangga dalam kegiatan penanaman menunjukkan curahan waktu ibu rumah tangga lebih tinggi yaitu 15,60 HKP dibandingkan pria 14,03 HKP dari kegiatan membuat lubang persemaian benih dan kegiatan mengangkut benih dan menanam. Pada kegiatan ini curahan waktu wanita sedikit lebih tinggi dibandingkan pria, artinya wanita sudah lebih banyak terlibat pada kegiatan penanaman. Hal ini berarti wanita sudah mampu mengaplikasikan pengetahuan yang didapat dari sosialisasi yang dilakukan bersama penyuluh yang rutin dilakukan pada saat atau sebelum program dijalankan.

Peranan yang dilakukan pada kegiatan pemeliharaan tanaman menunjukkan curahan waktu ibu rumah tangga lebih besar yaitu 29,30 HKP dibandingkan pria 12,53 HKP dari kegiatan memupuk tanaman, menyiram tanaman, mengendalikan hama dan penyakit dan menyulam. Lebih besarnya curahan waktu wanita pada pemeliharaan tanaman ini disebabkan karena menurut mereka pelaksanaan kegiatan ini dapat mereka lakukan sendiri sehingga turut campur tangan pria pun menjadi sangat minim pada kegiatan ini, karena wanita menganggap pemeliharaan tanaman ini bukan merupakan pekerjaan yang berat, dan wanita hanya meminta bantuan pria berupa saran hanya ketika terjadi ketidaksesuain kondisi tanaman. Dalam hal ini pria hanya mengarahkan wanita untuk melakukan respon yang cepat apabila ada tanaman yang terkena serangan hama dan penyakit.

Peranan ibu rumah tangga pada kegiatan pemanenan menunjukkan curahan waktu lebih tinggi yaitu 14,40 HKP dibandingkan pria 0,00 HKP dari kegiatan mencabut sayuran dan mengangkut sayuran. Pada kegiatan ini curahan waktu wanita lebih tinggi dibandingkan pria, dikarenakan pada kegiatan tidak adanya keterlibatan pria yang ikut membantu dalam proses pekerjaan. Hal ini dikarenakan pada kegiatan wanita melakukan gotong royong yang sudah dijadwalkan oleh Ketua kelompok wanita tani, ada 
pembagian tugas dan waktu kerja ketika panen mereka saling mebantu untuk melakukan kegiatan.

Peranan ibu rumah tangga pada kegiatan pemasaran hasil menunjukkan curahan waktu lebih tinggi yaitu 15,70 HKP dibandingkan pria 00,00 HKP dari kegiatan pengangkutan hasil dan penjualan hasil.. Pada kegiatan ini curahan waktu wanita lebih tinggi dibandingkan pria, dikarenakan pada kegiatan ini tidak adanya keterlibatan pria yang ikut membantu dalam proses kegiatan. Hal ini dikarenakan kegiatan tidak tergolong pekerjaan yang berat, dimana pada pemasarannya wanita menjual hasil panennya kepada warga sekitar tempat tinggal. Pemasaran hasil yang dilakukan terkadang ada tetangga yang ingin membeli, langsung datang kerumah untuk mendapatkan sayuran hasil kegiatan KRPL.

\section{KESIMPULAN}

Peranan ibu rumah tangga pada program KRPL di Kecamatan Natar termasuk ke dalam klasifikasi tinggi. Hal ini dibuktikan dengan tingginya peranan yang dilakukan ibu rumah tangga dalam penanaman, pemeliharaan tanaman, pemanenan dan pemasaran hasil pada program KRPL.

\section{DAFTAR PUSTAKA}

Badan Litbang Pertanian. 2012. Program Model Kawasan Rumah Pangan Lestari. Jakarta.

Farmia A. 2006. Peran perempuan Indonesia dalam pembangunan pertanian. Jurnal Ilmuilmu Pertanian, 2(1): 35 - $41 . \quad$ https:// media.neliti.com/media/publications/23060ID-analisis-peran-perempuan-dalam-pertani an-di-kecamatan-rasau-jaya-kabupaten-kubur .pdf. [25 Juni 2019].

Hernanda T, Indriani Y, Listiana I. 2013. Ketahanan pangan rumah tangga petani jagung di Kecamatan Simpang Kabupaten Ogan Komering Ulu (OKU) Selatan. JIIA, 1(4): 311-318. http://jurnal.fp.unila.ac.id /index.php/JIA/article/view/706. [25 Juni 2019].

Hubeis AVS. 2010. Pemberdayaan Perempuan Dari Masa ke Masa. IPB Press. Bogor.

Irawaty I dan darojat Z. 2019. Kedudukan dan peran perempuan dalam perspektif islam dan adat Minangkabau. Jurnal MIS, 3(1): 88 - 95. http://journal.unj.ac.id/unj/index.php/hayula /article/view/9265. [25 Juni 2019].

Kementerian Pertanian. 2011. Pedoman Umum Model Kawasan Rumah Pangan Lestari 52 hal. Jakarta.

Kirana YA, Effendi I, dan Silviyanti S. 2018. Peranan anggota Kelompok Wanita Tani (KWT) dalam mewujudkan Desa Agrowisata Sungai Langka Kecamatan Gedong Tataan Kabupaten Pesawaran. JIIA, 6(4): 415 - 421. http://jurnal.fp.unila.ac.id/index.php/JIA/art icle/view/3062. [25 Juni 2019].

Nurmayasari D dan Ilyas. 2014. Peran anggota Kelompok Wanita Tani (KWT) Laras Asri pada peningkatan kesejahteraan keluarga (studi deskriptif di Dusun Daleman Desa Kadirejo Kecamatan Pabelan Kabupaten Semarang). Jurnal of Non Formal Education and Community Empowerment, 3(2): 16 - 21. https://journal.unnes.ac.id/sju/index.php /jnfc /article/view/3728. [25 Juni 2019].

Peraturan Presiden No 22. 2009. Kebijakan Percepatan Penganekaragaman Konsumsi Pangan Berbasis Sumberdaya Lokal. Indonesia.

Purwaningsih Y. 2008. Ketahanan pangan: situasi, permasalahan, kebijakan, dan pemberdayaan masyarakat. Jurnal Ekonomi Pembangunan, 9(1): 21-27. http://journals. ums.ac.id/index.php/JEP/article/view/1028. [25 Juni 2019].

Rachmawati N. 2012. Peran Wanita Tani Dalam Pemanfaatan Pekarangan Sebagai Alternatif Untuk Pemenuhan Pangan dan Gizi Keluarga. Prosding Seminar Nasional Optimalisasi Pekarangan November 2012. Semarang.

Saptana, Sunarsih, dan Friyanto S. 2013. Analisis kebijakan dan program model kawasan rumah pangan lestari. Forum Penelitian Agro Ekonomi, 3(1): 67 - 87. https://media.neliti. com/media/publications/70334-ID-pros pekmodel-kawasan-rumah-pangan-lesta.pdf. [25 Juni 2019].

Susanti R dan Tantoro S. 2015. Peran istri dalam perekonomian keluarga di Desa Parit Baru Kecamatan Tambang Kabupaten Kampar. Jurnal Online Mahasiswa FISIP, 2(1): 9 - 22 https://jom.unri.ac.id/index.php/JOMFSIP/ar ticle/view/5021. [25 Juni 2019]. 